\title{
Perbedaan Kadar Liver Fatty Acid Binding Protein (L-FABP) Urine Penderita Diabetes Melitus Tipe 2 dengan Normoalbuminuria dan Mikroalbuminuria
}

\author{
Kristina Wiharjo, Noormartany, Hikmat Permana, Sylvia Rachmayati \\ Departemen Patologi Klinik Fakultas Kedokteran Universitas Padjadjaran \\ Rumah Sakit Dr. Hasan Sadikin Bandung
}

\begin{abstract}
Abstrak
Diabetes melitus (DM) merupakan salah satu penyebab end stage renal disease (ESRD), 20-40\% akan mengalami nefropati diabetik yang berkembang menjadi ESRD. Prevalensi nefropati diabetik meningkat pada DM tipe 2. Akumulasi stres oksidatif dapat menyebabkan peningkatan permeabilitas glomerulus sehingga menyebabkan peningkatan ekskresi albumin pada urine yang terbagi menjadi normoalbuminuria, mikroalbuminuria, dan makroalbuminuria. Kerusakan glomerulus terjadi setelah kerusakan tubulointerstisial ginjal yang menyebabkan penurunan aliran kapiler peritubular dan menyebabkan hipoksia. Liver fatty acid binding protein (L-FABP) berfungsi mengurangi hipoksia dengan mengikat stres oksidatif dan mengeluarkannya ke dalam urine. Penelitian ini bertujuan untuk menganalisis apakah terdapat perbedaan kadar L-FABP antara penderita DM tipe 2 normoalbuminuria dan mikroalbuminuria. Metode penelitian adalah observasional analitik dengan rancangan potong lintang. Subjek penelitian sebanyak 70 orang penderita DM tipe 2 dengan normoalbuminuria (38 orang) dan mikroalbuminuria (32 orang) yang diambil secara acak pada pasien yang datang ke Laboratorium Rawat Jalan Rumah Sakit Dr. Hasan Sadikin pada periode Juli-September 2012. Uji statistik menggunakan Uji Mann-Whitney. Hasil penelitian menunjukkan perbedaan bermakna kadar L-FABP urine pada normoalbuminuria dengan mikroalbuminuria dengan nilai $Z_{\mathrm{M}-\mathrm{W}}=3.513 ; \mathrm{p}<0,001$, median pada normoalbuminuria adalah 5 , dan mikroalbuminuria adalah 7 . Dari penelitian ini didapatkan kadar L-FABP urine meningkat karena kompensasi pembentukan stres oksidatif dan hipoksia yang terjadi sebelum kerusakan glomerulus. Simpulan, kadar L-FABP urine pada pasien DM tipe 2 dengan mikroalbuminuria lebih tinggi daripada pasien DM tipe 2 dengan normoalbuminuria. [MKB. 2014;46(2):83-7]
\end{abstract}

Kata kunci: Diabetes melitus tipe 2, kadar L-FABP urine, mikroalbuminuria, nefropati diabetik, normoalbuminuria

\section{Comparison of Urinary Liver-Fatty Acid Binding Protein (L-FABP) in Normoalbuminuria and Microalbuminuria in Type 2 Diabetes Mellitus Patients}

\begin{abstract}
Diabetes mellitus (DM) is the leading cause of the end stage renal disease (ESRD). Around 20-40\% patients with DM develop diabetic nephropathy and eventually progress into ESRD. Type $2 \mathrm{DM}$ has a greater prevalence to develop diabetic nephropathy. Oxidative stress accumulation can increase permeability of the glomerulus which results in increased urine albumin excretion, which is divided into three groups: normoalbuminuria, microalbuminuria and macroalbuminuria. Glomerulus dysfunction occurs after tubulointerstisial renal dysfunction which decreases peritubular capillary flow that leads to tubulointerstisial hypoxia. Liver fatty acid binding protein function is to reduce hypoxia by binding oxidative stress and excretes it into urine. The aim of this study was to analyze the differences in the urine L-FABP level between normoalbuminuria and microalbuminuria type 2 DM patients. The study design was observational analytic using cross-sectional method. Subjects were 70 DM type 2 patients with normoalbuminuria (38 patients) and microalbuminuria (32 patients). Statistical analysis was performed using the Mann Whitney test The results found that there were significant differences in levels of urine L-FABP between normoalbuminuria and microalbuminuria type $2 \mathrm{DM}$ patients $\left(\mathrm{Z}_{\mathrm{M}-\mathrm{W}}=3.513, \mathrm{p}<0.001\right)$ with medians of 5 and 7 in normoalbuminuria and microalbuminuria, respectively. The urine L-FABP level increased because of the oxidative stress and hypoxia that happened before the glomerulus dysfunction. In conclusion, urine L-FABP level in patients DM type 2 with microalbuminuria is higher than that of the normoalbuminuria. [MKB. 2014;46(2):83-7]
\end{abstract}

Key words: Diabetic nephropathy, L-FABP urine level, microalbuminuria, normoalbuminuria, type 2 DM

Korespondensi: Kristina Wiharjo, dr., Taman Harapan Indah Blok N No. 10 Jakarta Barat 11460, mobile, 08161323482, e-mail kim_apo88@yahoo.com 


\section{Pendahuluan}

Diabetes melitus (DM) yaitu suatu penyakit metabolik dengan karakteristik hiperglikemia kronik yang terjadi karena kelainan sekresi dan/ atau fungsi insulin, kerja insulin atau keduaduanya. Klasifikasi DM berdasarkan etiologinya terdiri atas DM tipe 1 (insulin dependent diabetes mellitus/IDDM), tipe 2 (non insulin dependent diabetes mellitus/NIDDM), dan tipe spesifik lain. Salah satu komplikasi DM adalah nefropati diabetik. Keadaan yang dapat timbul bersamaan dengan DM adalah hipertensi. Hipertensi dengan DM tipe 2 terdiagnosis bersamaan pada sepertiga penderita. ${ }^{1-3}$

Menurut World Health Organization (WHO) dan International Diabetes Foundation (IDF) diperkirakan jumlah penderita DM di Indonesia akan bertambah menjadi 12 juta pada tahun 2030 . Menurut WHO, angka kematian penderita DM di dunia sekitar 3,2 juta orang/ tahun dan usia DM di negara berkembang 35-64 tahun, sedangkan di negara maju $>65$ tahun. Diabetes melitus (DM) merupakan salah satu penyebab utama end stage renal disease (ESRD) yang dapat meningkatkan mortalitas penderita, dapat menurunkan kualitas kehidupan, dan juga meningkatkan pengeluaran biaya kesehatan. Penderita ESRD umumnya memerlukan terapi hemodialisis atau bahkan transplantasi ginjal. Sekitar $20-40 \%$ penderita DM tipe 1 dan tipe 2 akan mengalami nefropati diabetik yang selanjutnya berkembang menjadi ESRD. Prevalensi nefropati diabetik meningkat terutama pada penderita DM tipe 2, oleh karena peningkatan jumlah penderita DM tipe 2 seiring peningkatan usia harapan hidup penderita DM, obesitas, dan gaya hidup yang tidak sehat. Onset DM tipe 2 tidak jelas, maka American Diabetes Association (ADA) menyarankan pemeriksaan fungsi ginjal pada saat penderita DM tipe 2 didiagnosis. Hal ini sangat penting untuk dapat menilai komplikasi DM nefropati diabetik dan mencegah progresivitas penyakit tersebut. ${ }^{4,5}$

Diagnosis nefropati diabetik dapat ditegakkan jika kadar albumin urine 24 jam $>30 \mathrm{mg}$ pada 2 dari 3 kali pemeriksaan dalam kurun waktu 3 sampai 6 bulan, tanpa penyebab albuminuria lainnya berdasarkan Perkumpulan Endokrinologi Indonesia (PERKENI) dan ADA. Pengumpulan urine 24 jam tidak praktis sehingga diperlukan metode pengukuran albumin urine yang lebih praktis. Salah satu metode skrining pemeriksaan kadar albumin dalam urine yang dianjurkan ADA yaitu perhitungan ekskresi kadar albumin urine sewaktu. Peningkatan ekskresi albumin dalam urine terjadi pada kerusakan glomerulus. Pada nefropati diabetik dini sebelum terjadi disfungsi glomerulus, maka hiperglikemia kronik akan menyebabkan stres oksidatif sehingga terjadi kerusakan mikrovaskular dan penurunan aliran darah kapiler peritubular yang akhirnya dapat menimbulkan hipoksia tubulointerstisial ginjal. Kadar albumin urine akan meningkat pada kerusakan glomerulus yang dapat terjadi setelah kerusakan tubulointerstisial. Hal ini menunjukkan diperlukan suatu penanda penurunan fungsi ginjal lebih dini untuk mendeteksi nefropati diabetik. ${ }^{3,5,6}$

Liver fatty acid binding protein (L-FABP) merupakan protein sitosol berukuran 14-15 $\mathrm{kD}$ yang diekspresikan dan diekskresikan sel hati, tubulus proksimal ginjal, usus, pankreas, paru-paru, dan juga abdomen. Fungsi L-FABP untuk dapat mengurangi stres oksidatif sehingga terjadi hipoksia reoksigenasi. Kadar L-FABP yang dapat dideteksi dalam urine mempunyai keunggulan karena ditemukan pada keadaan hipoksia tubulointerstisial ginjal sehingga dapat mendeteksi nefropati diabetik secara dini. ${ }^{7,8}$

Pada ginjal manusia, L-FABP diekspresikan dan diekskresikan di tubulus proksimal yang menggunakan asam lemak bebas sebagai sumber metabolisme. Pada proses fisiologis albumin dan asam lemak bebas akan direabsorbsi pada tubulus bagian proksimal. Setelah terjadi proses reabsorbsi, albumin sitosol akan dipindahkan ke lisosom dan asam lemak akan dibebaskan. Asam lemak yang dibebaskan ini akan diikat oleh L-FABP, selanjutnya asam lemak yang terikat dengan L-FABP akan direlokasi ke peroksisom sitosolik untuk mengalami proses peroksidasi. Pada keadaan iskemik, lipid yang mengalami peroksidasi berupa 4-hydroxynonenal (HNE) yang bersifat sitotoksik akan terakumulasi pada tubulus proksimal. Pembentukan stres oksidatif ini terjadi terus menerus sehingga akan merusak tubulus proksimal. Liver fatty acid binding protein akan mengikat lipid sitotoksik, advanced glycan end products (AGEs), reactive oxygen species (ROS), radikal hidroperoksida, serta mengeluarkannya ke dalam urine. Pengeluaran L-FABP ini akan mengurangi stres oksidatif yang terjadi pada tubulus proksimal. Kerusakan tubulus proksimal ginjal akan menurunkan aliran darah di kapiler peritubular sehingga menyebabkan keadaan hipoksia. Gen promotor dari L-FABP mengandung hypoxia response element (HRE) sehingga hipoksia akan meningkatkan ekspresi dari L-FABP. ${ }^{8,9}$

\section{Metode}

Subjek penelitian ini adalah penderita yang didiagnosis DM tipe 2 yang berusia 35-64 tahun dengan normoalbuminuria dan mikroalbuminuria yang datang ke Laboratorium Rawat Jalan Poli 
Departemen Patologi Klinik Rumah Sakit Dr. Hasan Sadikin Bandung pada periode JuliSeptember 2012. Jumlah sampel penelitian adalah 70 orang. Kriteria eksklusinya adalah penderita yang telah mengalami gagal ginjal dan gangguan hati. Penelitian ini mengikutsertakan seluruh pasien DM tipe 2 yang datang ke Laboratorium Rawat Jalan RSHS Bandung yang memenuhi kriteria inklusi tanpa memandang jenis terapi yang telah diberikan kepada pasien tersebut.

Penelitian ini dilaksanakan dengan metode observasional analitik dengan rancangan potong lintang. Subjek penelitian diambil secara acak. Seluruh subjek penelitian yang memenuhi kriteria inklusi diberikan penjelasan mengenai penelitian ini. Setelah subjek penelitian setuju untuk ikut serta dalam penelitian maka subjek penelitian diminta untuk menandatangani kesediannya (informed consent). Selanjutnya subjek penelitian diminta untuk mengumpulkan urine sewaktu. Urine subjek penelitian yang telah dikumpulkan disentrifugasi 3.000 menit/rpm 15 detik dan supernatan disimpan pada $-80^{\circ} \mathrm{C}$ sampai jumlah sampel terpenuhi. Seluruh urine yang telah terkumpul dilakukan pemeriksaan albuminuria yang dikelompokkan menjadi dua kelompok yaitu normoalbuminuria dan mikroalbuminuria. Setelah itu, baru dilakukan pemeriksaan L-FABP urine.

Variabel bebas yaitu penderita DM tipe 2 dengan normoalbuminuria dan mikroalbuminuria, sedangkan variabel tergantung kadar L-FABP urine. Pemeriksaan L-FABP urine menggunakan metode sandwich enzymelinkedimmunoabsorbent assay (ELISA) dan pemeriksaan albuminuria menggunakan metode imunoturbidimetri.

Uji statistik yang digunakan untuk menilai karakteristik subjek penelitian berdasarkan usia dan jenis kelamin menggunakan chi-kuadrat, sedangkan uji statistik untuk menilai perbedaan kadar L-FABP pada normoalbuminuria dan mikroalbuminuria mempergunakan Uji MannWhitney dengan nilai kemaknaan $p<0,05$. Data yang telah dikumpulkan diolah dengan program SPSS versi Windows 17.0.

\section{Hasil}

Penderita DM tipe 2 dengan normoalbuminuria dan mikroalbuminuria lebih banyak terdapat pada perempuan yaitu 47 orang dibandingkan dengan laki-laki yaitu 23 orang dengan hasil analisis uji chi-kuadrat adalah $\mathrm{p}=0,448(\mathrm{p}>0,05)$ (Tabel 1). Jumlah subjek penelitian paling banyak berusia $\geq 60$ tahun yaitu 32 orang, sedangkan jumlah subjek penelitian paling sedikit berusia $<50$ tahun yaitu 9 orang dengan hasil analisis uji chi-kuadrat adalah $\mathrm{p}=0,281(\mathrm{p}>0,05)$.

Berdasarkan uji statistik tersebut karakteristik subjek penelitian berdasarkan jenis kelamin dan usia antara kedua kelompok subjek penelitian tersebut dapat diperbandingkan, sehingga dapat dianalisis lebih lanjut.

Kadar L-FABP urine pada kelompok DM tipe 2 dengan normoalbuminuria lebih rendah bila dibandingkan dengan kelompok DM tipe 2 dengan mikroalbuminuria. Uji normalitas kadar L-FABP urine pada ke-2 kelompok menggunakan Uji Shapiro-Wilk dengan nilai $\mathrm{p}<0,001$ yang menunjukkan bahwa data tidak berdistribusi normal dengan hasil Uji Mann-Whitney adalah $\mathrm{Z}_{\mathrm{M}-\mathrm{W}}=3,513 ; \mathrm{p}<0,001$. Keadaan ini menunjukkan terdapat perbedaan bermakna kadar L-FABP urine

Tabel 1 Karakteristik Subjek Penelitian

\begin{tabular}{lcc}
\hline \multirow{2}{*}{ Karakteristik } & \multicolumn{2}{c}{ Kelompok Penelitian } \\
\cline { 2 - 3 } & $\begin{array}{c}\text { DM Tipe 2 dengan Normoalbuminuria } \\
(\mathbf{n}=\mathbf{3 8})\end{array}$ & $\begin{array}{c}\text { DM Tipe 2 } \\
\mathbf{d}\end{array}$ \\
\hline Jenis kelamin & & $\mathbf{3 2})$ \\
$\quad$ Laki-laki & 11 & 12 \\
$\quad$ Perempuan & 27 & 20 \\
Usia (tahun) & 3 & 6 \\
$\quad<50$ & 15 & 14 \\
$50-59$ & 20 & 12 \\
$\geq 60$ & 58,74 & 55,41 \\
Mean & 60 & 56 \\
Median & $45-64$ & $36-64$ \\
Rentang & & \\
\hline
\end{tabular}


Tabel 2 Perbedaan Kadar L-FABP Urine pada DM Tipe 2 dengan Normoalbuminuria dan Mikroalbuminuria

\begin{tabular}{lcccc}
\hline \multirow{2}{*}{$\begin{array}{c}\text { Kadar L-FABP } \\
(\mathbf{n g} / \mathbf{m L})\end{array}$} & \multicolumn{2}{c}{ Kelompok Penelitian } & & \\
\cline { 2 - 4 } & $\begin{array}{c}\text { DM Tipe 2 dengan } \\
\text { Normoalbuminuria } \\
(\mathbf{n}=\mathbf{3 8})\end{array}$ & $\begin{array}{c}\text { DM Tipe 2 dengan } \\
\text { Mikroalbuminuria } \\
(\mathbf{n}=\mathbf{3 2})\end{array}$ & $\mathbf{Z}_{\mathrm{M}-\mathbf{w}}$ & $\mathbf{p}$ \\
\hline Median & 5 & 7 & 3,513 & $<0,001$ \\
Rentang & $3-11$ & $4-176,8$ & \\
\hline
\end{tabular}

Keterangan: $\mathrm{Z}_{\mathrm{M}-\mathrm{W}}$ : Uji Mann Whitney $(\mathrm{p}<0,05=$ berbeda bermakna)

antara kelompok penelitian DM tipe 2 dengan normoalbuminuria dan mikroalbuminuria.

\section{Pembahasan}

Penderita wanita DM tipe 2 pada penelitian ini lebih banyak bila dibandingkan dengan laki-laki (Tabel 1). Hal ini disebabkan penurunan estrogen sebagai akibat penurunan produksi estrogen pada ovarium. Penurunan estrogen ini mengubah testosteron adrenal dan androstenedion menjadi $17 \beta$ estradiol dan estron yang terjadi pada jaringan adiposa. Perubahan ini diperantarai oleh enzim aromatase yang aktivitas peningkatannya seiring dengan peningkatan usia. Peranan estrogen yaitu meningkatkan sensitivitas insulin, pengeluaran insulin di sel beta pankreas, dan kerja insulin sehingga penurunan estrogen dapat menyebabkan resistensi insulin. ${ }^{10,11}$

Jumlah pasien normoalbuminuria ini lebih besar daripada pasien mikroalbuminuria (Tabel 1). Hal ini disebabkan karena pasien DM tipe 2 denganhipertensi yang biasanya terjadi bersamaan seiring dengan perjalanan DM telah mendapat terapi antihipertensi misalnya angiotensinogen converting enzyme (ACE) inhibitor atau angiotensin reseptor blocker (ARB). Seluruh subjek penderita yang menderita DM tipe 2 dengan atau tanpa hipertensi telah diberikan terapi renoprotektif. Kedua obat antihipertensi tersebut bersifat renoprotektif yang mampu mencegah progresivitas nefropati diabetik. Kerja kedua obat tersebut adalah memblokade renin angiotensin system (RAS) sehingga terjadi penurunan tekanan intraglomerular yang akhirnya akan menurunkan ekskresi albumin dalam urine. , $, 7,12^{2}$

Kadar L-FABP urine pada mikroalbuminuria lebih tinggi daripada normoalbuminuria (Tabel 2). Keadaan ini disebabkan pembentukan stres oksidatif pada DM tipe 2 yang terjadi karena proses hiperglikemia kronik dan gangguan klirens asam lemak. Pembentukan stres oksidatif yang terjadi adalah AGEs, ROS, dan pembentukan lipid peroksida sebagai hasil gangguan klirens asam lemak. Pembentukan stres oksidatif ini akan merusak jaringan tubulointerstisial yang akan menurunkan aliran kapiler peritubular sehingga terjadi hipoksia jaringan tubulus ginjal. Liver fatty acid binding protein adalah protein sitosol yang diekspresikan dan diekskresikan tubulus proksimal ginjal dan gen promotornya mempunyai hypoxia response element (HRE) yang akan meningkatkan ekspresi L-FABP. Fungsi L-FABP untuk mengikat stres oksidatif seperti lipid sitotoksik, ROS, dan radikal hidroperoksida sehingga terjadi hipoksia reoksigenasi. Stres oksidatif yang terbentuk akan semakin tinggi seiring dengan tingkat keparahan penyakit yang diperkuat dengan hipoksia kronik, maka semakin banyak jumlah L-FABP yang akan dikeluarkan di dalam urine. Pengeluaran L-FABP terjadi karena kompensasi pembentukan stres oksidatif dan hipoksia yang terjadi sebelum kerusakan glomerulus yang akhirnya akan meningkatkan ekskresi albumin dalam urine. ${ }^{9,13-16}$

Penelitian ini memiliki keterbatasan tidak dilakukannya pendataan terapi yang diberikan pada subjek penelitian seperti antilipemik, ACE inhibitor, serta ARB yang bersifat renoprotektif berpengaruh pada ekskresi albumin dalam urin dan kadar L-FABP. Pada penelitian ini juga penapisan faktor eksklusi penderita gangguan hati dan penderita sepsis hanya berdasarkan anamnesis dan diagnosis dari klinisi. Simpulan, kadar L-FABP urine pada penderita DM tipe 2 dengan mikroalbuminuria lebih tinggi daripada penderita DM tipe 2 dengan normoalbuminuria. Perlu penelitian lanjutan untuk menilai validitas L-FABP urine sebagai penanda dini kerusakan ginjal penderita DM tipe 2 .

\section{Daftar Pustaka}

1. American Diabetes Association. Diagnosis and classification of diabetes mellitus. Diabetes Care. 2004;27(Suppl1):55-60. 
2. Buse JB, Polonsky KS, Burant CF. Type 2 diabetes mellitus. Dalam: Larsen PR, Kronenberg HM, Melmed S, Polonsky KS, penyunting. William textbook of endocrinology. Edisi ke-10. Amerika Serikat: Saunders; 2003. hlm. 1427-84.

3. Konsensus Pengendalian dan Pencegahan Diabetes Mellitus Tipe 2 di Indonesia 2011. Jakarta: Perhimpunan Endokrinologi Indonesia; 2011.

4. World Health Organization, International Diabetes Foundation. Definition and diagnosis of diabetes mellitus and intermediate hyperglycemia: report of a WHO/IDF consultation. Switzerland: WITO; 2006.

5. American Diabetes Association. Nephropathy in diabetes. Diabetes Care. 2004;27(Suppl 1): S79-83.

6. American Diabetes Association. Standards of medical care in diabetes-2011. Diabetes Care. 2011;34(Suppl 1):S11-61.

7. Gross JL, Azevedo MJD, Silveiro SP, Canani LH, Caramori ML, Zelmanovitz T. Diabetic nephropathy: diagnosis, prevention, and treatment. Diabetes Care. 2005;28(1):164-76.

8. Kamijo-Ikemori A, Sugaya T, Yasuda T, Kawata T, Ota A, Tatsunami S, dkk. Clinical significance of urinary liver-type fatty acid binding protein in diabetic nephropathy of type 2 diabetic patients. Diabetes Care. 2011;34(3):691-6.

9. Newberry EP, Davidson NO. Liver fatty acid binding protein (L-FABP) as a target for the prevention of high fat diet induced obesity and hepatic steatosis. Curr Med Chem Immunol Endocr Metab Agents. 2009;9(1):30-7.

10. Meyer MR, Clegg DJ, Prossnitz ER, Barton M. Obesity, insulin resistance and diabetes: sex differences and role of estrogen receptors. Acta Physiol. 2011;203(1):259-69.

11. Wild S, Roglic G, Green A, Sicree R, King $\mathrm{H}$. Global prevelance of diabetes: estimates for the year 2000 and projections of 2030. Diabetes Care. 2004;7(5):1047-53.

12. Mojto P, Tison P. Principles of prevention and therapy in diabetic nephropathy. Bratisl Lek Listy. 2004;105(12):432-3.

13. Satchell SC, Tooke JE. What is the mechanism of microalbuminuria in diabetes: a role for the glomerular endothelium? Diabetologia. 2008;51:714-25.

14. Glassock RJ. Is the presence of microalbuminuria a relevant marker of kidney disease? Curr Hypertens Rep 2010;12(5):364-8.

15. Furuhashi M, Hotamisligil GS. Fatty acidbinding proteins:role in metabolic diseases and potential as drug targets. Nat Rev Drug Discov. 2008;7:489-503.

16. Noiri E, Doi K, Negishi $K$, Tanaka T, Hamasaki Y, Fujita T, dkk. Urinary fatty acid-binding protein 1: an early predictive biomarker of kidney injury. Am J Physiol Renal Physiol. 2009;296(4):F669-79. 